\title{
Can crop diversification be widely adopted to solve the water crisis in Punjab?
}

\author{
Shruti Bhogal* and Kamal Vatta
}

The disquieting water crisis in Punjab - the food bowl of India - is threatening its agricultural sustainability, necessitating effectuation of pragmatic policy measures. Conventional agricultural practices, especially the paddy-wheat (highly water-intensive crops) cropping system, are fuelling the growing water challenges. Large-scale crop diversification is being recommended by experts for the past four decades as one of the most potent solutions for attaining water and agricultural sustainability. Despite its merits, crop diversification in the state could not bear fruits and remains almost inconclusive. The present article collates empirical studies to ascertain handicaps associated with crop diversification in Punjab for framing an indefectible crop diversification policy. Such a policy cannot be implemented in isolation but requires multifaceted policy action with the Government playing a key role.

Keywords: Agricultural sustainability, crop diversification, paddy, policy measures, water crisis.

INCREASING consciousness about growing challenges of water sustainability, and the subsequent socio-economic and ecological vulnerabilities: life sustenance, agricultural sustainability, food availability and livelihood generation, is fostering a constructive discourse on sustainable use of global water resources ${ }^{1-4}$. An urgent need for viable solutions to mitigate unsustainable water use is universally acknowledged, and suitable measures are being taken the world over ${ }^{5-7}$.

Unpropitious agricultural practices have been fomenting groundwater deterioration in India. The IndoGangetic Plains in northwest India is facing aggravated challenges of groundwater depletion due to excessive and inefficient use of water in agriculture. The situation has reached alarming levels in Punjab which is the pioneer of green revolution in India that was driven by paddy-wheat cultivation. In contrast to historical records of agriculture in the villages of Punjab that show a large number of crops being grown by farmers in the past ${ }^{8}$, the post-green revolution period exhibits a decline in crop diversity 9 . Majority of farmers in the state continue to prefer paddywheat cultivation $^{10,11}$. Thus, the area under paddy continues to increase, from 0.39 million ha in 1970-1971 to 3.1 million ha in 2018-2019.

Dominance of paddy-wheat cropping system that fostered food self-sufficiency in India is now being impacted on account of intensive water requirements. In particular,

Shruti Bhogal is in the Centers for International Projects Trust, New Delhi 110 017, India; Kamal Vatta is in the Department of Economics and Sociology, Punjab Agricultural University, Ludhiana 141 004, India.

*For correspondence. (e-mail: shrutibhogal@gmail.com) paddy crop is blamed for increasing groundwater exploitation and ever-rising agri-water challenges in Punjab. Paddy consumes more water compared to any other crop $^{12}$. Moreover, the conventional practices of paddy irrigation are water-inefficient ${ }^{13}$. Thus, given the semiarid soils of the state, cultivation of paddy is increasingly being considered detrimental to its groundwater and agricultural sustainability.

Overdependence of current agricultural practices on groundwater is manifesting a dire water situation in the state. Groundwater aquifers in about $79 \%$ of the total area of Punjab are overexploited ${ }^{14}$. Empirical evidence highlights that if this existing trend continues, the state is headed towards a 'water crisis' with impending desertification $^{15}$. Of the total 138 development blocks in Punjab, groundwater resource is overexploited in 109 blocks, critical in 2 blocks and semi-critical in 5 blocks, thus, pointing towards an alarming groundwater situation. Average depth of the water table has intensified over time, from $7.32 \mathrm{~m}$ in 1998 to $12.79 \mathrm{~m}$ in 2012 (ref. 16). Groundwater in Punjab is depleting at a startling rate of $0.37 \mathrm{~m} / \mathrm{yr}$ (ref. 17). This trend is widely expected to adversely affect agricultural productivity and will be deleterious to the pace and pattern of future agricultural development in the state ${ }^{18}$. It is an established fact that Punjab's agriculture has the largest contribution to India's food stock, thus, making the state's agriculture indispensable to the nation's food security. Therefore, the threat that water challenges pose to Punjab's agricultural sustainability necessitates adding new dimensions - that focus on water sustainability - to the policy narrative of its growth trajectory. 


\section{Crop diversification: an optimistic solution to water crisis}

Crop diversification, that aims at replacing waterguzzling paddy - currently cultivated on over $85 \%$ of the cropped land - with less water-intensive crops, is being viewed as a felicitous strategy to mitigate agri-water challenges in Punjab ${ }^{19-22}$. The literature indicates several benefits of crop diversification: groundwater conservation, revitalization of soil through cultivation of nitrogenfixing crops, improved productivity, resource use efficiency, ecological gains, strengthening of rural nonfarm sector and employment generation, and sustainable agriculture ${ }^{23-27}$. In the past, various expert committees have advocated crop diversification as the most potent solution $^{28,29}$. The recently constituted high-level committee led by Montek Singh Ahluwalia (2020) also suggested crop diversification for achieving water sustainability and revival of the agriculture sector in Punjab ${ }^{30}$. The state targets to shift 1.2 million ha paddy (out of total 3 million ha) to alternative crops for groundwater conservation ${ }^{21}$. However, most of the efforts for crop diversification since mid-1980s have not yielded any success ${ }^{31-36}$.

Despite the potential of crop diversification to improve sustainability of both water and agriculture, majority of farmers in Punjab are reluctant to adopt it. This article highlights multiple challenges to expansive adoption of crop diversification in Punjab along with essential constructive policy actions based on empirical research literature.

\section{Factors discouraging crop diversification}

Widespread crop diversification seems to be a far-fetched idea for Punjab agriculture, cetris paribus. Experts often stress that populous policy environment of Punjab agriculture, fashioned by both State and Central Governments, has constricted change in agricultural practices. The currently effective policies of minimum support price (MSP) and assured procurement, free electricity, easy and subsidized purchase of submersible pumps and fertilizers, give an impetus to the dominant and age-old wheat and paddy cropping pattern ${ }^{37,38}$. Considering alternative crops, as of now, even the policy-endorsed ones discernibly lack such support, especially price and procurement support. Inadequacies of facilitative measures have created an inimical environment for widespread adoption of crop diversification ${ }^{39}$.

MSP and public procurement are crucial points of contention when it comes to promotion of crop diversification at the national level ${ }^{40}$. Studies show that of all the crops with MSP in the country, only a few are effectively procured $^{41}$. Possibility of abatement in profitability - the prime fear of farmers manifesting from the policy push for other crops - has held back farmers for long from experimenting with crops that are not backed by assured procurement. In the case of Punjab, mainly wheat and paddy are procured ${ }^{42}$, while other crops have suffered at the hands of private companies due to lack of effective implementation of $\mathrm{MSP}^{43}$. Public procurement of crops other than paddy and wheat is non-existent in the state. Thus, farmers consider the adoption of alternative crops as an unconvincing option. Despite the annual announcement of MSP for 24 crops by the Government, many farmers are unaware of the very existence of MSP for alternative crops. A study revealed that only 53\% and $49 \%$ of farmers in Punjab were aware about MSP of all rabi and kharif crops respectively ${ }^{44}$, thus explaining the unpopularity of alternative crops.

Additionally, many studies have highlighted that infrastructural insufficiencies and inadequate public and private investments in agricultural infrastructure hinder crop diversification ${ }^{45,46}$. It is noteworthy that almost all the marketed surplus of paddy and wheat in the state is procured by the Government. Thus, there is no need for farmers to arrange for storage facilities. However, alternative crops, especially fruits and vegetables, require large storage facilities, specifically cold storage. The fact that only $2-3 \%$ of India's horticulture output is stored in cold storage facilities and $30 \%$ of the horticulture produce goes waste due to inadequacy of such facilities highlights the rationale behind not adopting crop diversification $^{47}$. Insufficient and uneconomical storage space for potato farmers is a common story in Punjab. According to the NITI Aayog Report of the Task Force for Agricultural Development in Punjab ${ }^{48}$, post-harvest losses for fruits and vegetables, which were around $20 \%$, and postharvest handling and management inefficiencies, like lack of grading, standardization, and scientific packaging, are major bottlenecks to the adoption of high value crops (HVCs) in the state. Naturally, this would engender anxieties regarding cultivation of any crops other than wheat and paddy. Therefore - in the absence of public procurement for alternative crops - the lack of storage space constrains the potential for profitability as farmers would suffer post-harvest losses, and would be unable to undertake staggered sales. Furthermore, requirement of increased capital investment for machinery and paraphernalia for alternative crops is also a common constraint.

Additionally, weak forward linkages of agriculture, particularly agri-processing industrial units, have withheld widespread adoption of crop diversification in the state $^{27}$. According to NITI Aayog, lack of agri-processing and value addition in the state is confining crop diversification $^{48}$. Agricultural processing, in both organized and unorganized sectors, accounts for merely $2.2 \%$ of Punjab's agricultural production. Limitations in widespread development of value-adding industries in the state restrict marketing avenues for alternative crops. Furthermore, unlike wheat and paddy, which are staple food for most of the country, alternative crops suffer from a lack 
of comparable demand and easy marketability. Not to mention, markets for such crops are often riddled with imperfections ${ }^{49,50}$.

\section{Crop diversification: a point in case for large landholdings}

Theoretical and empirical evidences suggest that viability of crop diversification is limited to small farms alone. The literature points towards an inverse relationship between landholding size and diversification ${ }^{51,52}$. Shergill $^{53}$ reported that cultivation of multiple crops per season is an inherent trait of subsistence farming it is the natural outcome of the autarkic state of a subsistence farming'. The study highlights that crop diversification is highly incompatible with modern commercial farming that comprises large farm sizes $(>2$ ha) that require specialization in crops for profit-making. In addition, the macro market structure promotes specialization in a single crop by large commercial farms with sufficiently large marketed surplus. With monoculture staying put, the study argues that the ramifications of monoculture, like declining water table and environmental degradation, need to be tackled by legislative measures.

The beneficial entailments of a multidimensional policy approach towards crop diversification, the major one being its improved acceptability among farmers, will not be exclusive to any particular strata; rather it has the potential to effect a widespread change among the farming community in general. Nonetheless, widespread adoption of crop diversification needs to be encouraged among farmers with landholding more than 2 ha, who comprise majority of the agricultural households in the state and with maximum contribution in its marketable surplus.

\section{Pathways to widespread adoption of crop diversification}

The foremost policy measure in this regard would be to design optimal crop plans which recommend cropping patterns that would maximize net returns and ensure significant groundwater saving ${ }^{21}$; and also assuring remunerative prices or MSP, and mandating effective public and private procurement on the stipulated prices, which would further encourage a shift to new crops ${ }^{54}$. MSP for fruits and vegetables announced by the Government of Kerala, is an initiative in this direction. Institutions like Gram Panchayats, NGOs and cooperative societies can be engaged to assist the Government in implementing and delivering on planned patterns of regional cropping ${ }^{51}$. Noticeably, given the stringent water-energy nexus of paddy cultivation, a shift away from this crop would generate positive externalities that can be accounted in terms of water and electricity savings ${ }^{55}$. The savings so generated, if passed onto the farmers through incentives for adoption of alternative crops, would be a win-win situation for all. Subsidizing inputs, at least initially, would be invaluable towards providing the required impetus to crop diversification. Also, easy or cheaper credit availability for diversification is an essential monetary motivation ${ }^{56}$. In addition, subsidized crop insurance is of paramount importance to foster crop diversification ${ }^{55}$. A study in Odisha by Basantray and Nancharaiah ${ }^{57}$, highlighted the relationship between cooperative societies and crop diversification. It was found that farmers who were dependent on cooperative societies for credit were practising diversification more than those who borrowed from other sources. Further, extensive training and awareness campaigns regarding technical and financial aspects of crop diversification would encourage wilful acceptance ${ }^{58}$.

A report by NITI Aayog suggests legislative reforms and reorientation of policies for development and strengthening of agricultural marketing ${ }^{59}$. Identification and strengthening of supply chains and value chains to create ample market for recommended crops, and delivering profitability to farmers is critical for Punjab ${ }^{22,60,61}$. In this direction, setting up of processing and other supplementary industries in rural areas would generate value for the agricultural sector, and also boost rural non-farm employment $^{62,63}$. Furthermore, horizontal diversification backed by state or regional-level crop planning, and vertical diversification - in the form of rural industrialization - would usher in a climate of economic optimism that could induce a breakaway from rooted agricultural practises. Experiences of a number of Asian countries, like South Korea, Indonesia and the Philippines - with relatively smaller farm sizes than those of India, but better agricultural income - indicate the significance of vertical and horizontal diversification in comprehensive development ${ }^{51}$. However, the dilemma of precedencewhether markets and industries for alternative crops need to be established first, or widespread cultivation of such crops - is a 'chicken-and-egg problem'. This presents the danger of policy planning going around in circles, which should be strategically avoided by policymakers. Since crop diversification has been established as a vital instrument for achieving water and agricultural sustainability. It becomes incumbent on the Government to promote a shift towards less water-intensive crops, and also propel water-use efficiency in the existing and recommended alternative crops.

To conclude, crop diversification can be a solution to the water challenges in Punjab. Nonetheless, effective policies that would ensure remunerative commercial farming - produce not to be procured at less than MSP of alternative crops, create marketing infrastructure, strengthen market information and intelligence, increase public and private investment in rural infrastructure, propel research and extension services, and provide credit assurance and risk insurance for recommended alternative crops and varieties are quintessential for the transformation 
of traditional monoculture towards less water-intensive crops and more water-efficient agricultural practices. That it is crucial for farmers to realize the impending threat to agricultural sustainability, and act towards aversion of consequent catastrophic results while contributing towards macro goals, is beyond doubt. Concurrently, it is imperative for policymakers to provide a firm foundation, both socio-economic and political, giving impetus to the economic well-being of farmers. In the end, this may well be the decisive factor that empowers Punjab's farmers to make an impactful contribution towards environmental sustainability.

1. Baumgartner, T. and Pahl-Wostl, C., UN - Water and its role in global water governance. Ecol. Soc., 2013, 18(3), 3.

2. WWAP, The United Nations World Water Development Report, Water for a sustainable world, UNESCO, Paris, 2015.

3. WWC, Sharing water, 8th World Water Forum, Brasilia 2018, World Water Council, Brazil, 2018.

4. Weigleb, V. and Bruns, A., What is driving the water-energy-food nexus? Discourses, knowledge, and politics of an emerging resource governance concept. Front. Environ. Sci., 2018; https:// doi.org/10.3389/fenvs.2018.00128 (accessed on 19 September 2020).

5. GoI, National Water Mission. Government of India, 2011; http://nwm.gov.in/?q=schemes (accessed on 14 August 2020).

6. Roy, A. and Pramanick, K., Analysing progress of sustainable development goal 6 in India: past, present, and future. J. Environ. Manage., 2019, 232, 1049-1065.

7. UN, The sustainable development goals report. United Nations, 2020; https://unstats.un.org/sdgs/report/2020/

8. GoP, The Board of Economic Enquiry. Government of Punjab, Chandigarh, 1931

9. Mann, R. S., Cropping pattern in Punjab (1966-67 to 2014-15) Econ. Polit. Wkly, 2017, 52(3), 30-33.

10. Sarkar, A. and Das, A., Groundwater irrigation-electricity-crop diversification nexus in Punjab: trends, turning points, and policy initiatives. Econ. Polit. Wkly, 2014, 49(52), 64-73.

11. Singh, S., Park, J. and Litten-Brown, J., The economic sustainability of cropping systems in Indian Punjab: a farmers' perspective. In Change and Uncertainty Challenges for Agriculture, Food and Natural Resources, EAAE Congress, Zurich, Switzerland, 30 August to 2 September 2011

12. Sidhu, R. S., Vatta, K. and Dhaliwal, H. S., Conservation agriculture in Punjab - economic implications of technologies and practices. Indian J. Agric. Econ., 2010, 65(3), 413-427.

13. FAO, Rice and diversified water: a long and diversified story, Food and Agriculture Organization, 2004; http://www.fao.org/ rice2004/en/f-sheet/factsheet1.pdf (accessed on 2 August 2020).

14. GoP, Statistical abstract of Punjab. Government of Punjab, Chandigarh, 2018.

15. Kumar, R., Vaid, U. and Mittal, S., Water crisis: issues and challenges in Punjab. In Water Resource Management (eds Singh, V. P., Yadav, S. and Narayan, R.), Springer, Singapore, 2018, pp. 93-103.

16. Baweja, S., Aggrawal, R. and Brar, M., Groundwater depletion in Punjab, India. In Encyclopaedia Soil Sci. (ed. Lal, R.), 2017, 3rd edn, pp. $1-5$.

17. GoP, Ground water resource of Punjab State. Water Resource and Environment Directorate, Central Ground Water Board North Western Region, Government of Punjab, Chandigarh, 2018.

18. Kaur, S., Aggarwal, R. and Brar, M. S., Groundwater depletion in Punjab. Encyclopaedia Soil Sci., 2017, 3, 1-16.

19. Sidhu, R. S., Vatta, K. and Lall, U., Climate change impact and management strategies for sustainable water-energy-agriculture outcomes in Punjab. Indian J. Agric. Econ., 2011, 66(3), 328339.

20. Perveen, S. et al., Restoring groundwater in Punjab, India's breadbasket: finding agricultural solutions for water sustainability. Columbia Water Center White Paper, Earth Institute, Columbia University, USA, 2012.

21. Kaur, B., Vatta, K. and Sidhu, R. S., Optimising irrigation water use in Punjab agriculture: role of crop diversification and technology. Indian J. Agric. Econ., 2015, 70(3), 307-318.

22. Chhatre, A., Devalkar, S. and Seshadri, S., Crop diversification and risk management in Indian agriculture. Decision, 2016, 43, $167-179$.

23. Srivastava, S. K., Chand, R., Singh, J., Kaur, A. P., Jain, R., Kingsly, I. and Raju, S. S., Revisiting groundwater depletion and its implications on farm economics in Punjab, India. Curr. Sci., 113(3), 422-429.

24. Chakrabarty, S. and Kundu, A., Rural non-farm economy: a note on the impact of crop-diversification and land-conversion in India. Econ. Polit. Wkly, 2009, 44(12), 69-75.

25. Kaur, I., Need of crop diversification to achieve sustainable agriculture in Punjab: a brief review. Indian J. Econ. Dev., 2015, 11(1), 41-50.

26. Sidhu, H. S., Crisis in agrarian economy in Punjab: some urgent steps. Econ. Polit. Wkly, 2002, 37(30), 3132-3138.

27. Luce, M. St. et al., Diversifying cropping systems enhances productivity, stability, and nitrogen use efficiency. Agron. J., 2020; https://acsess.onlinelibrary.wiley.com/doi/pdf/10.1002/agj2.20162 (accessed on 6 November 2020).

28. Johl, S. S., Diversification of agriculture in Punjab. Report of Expert Committee, Government of Punjab, Chandigarh, 1986.

29. Johl, S. S., Agricultural production pattern adjustment programme in Punjab for productivity and growth, Government of Punjab, Chandigarh, 2002.

30. Hussain, S., It's time to make Punjab agriculture great again. But how to do so? The Wire, 1 September 2020; https://thewire.in/ agriculture/punjab-agriculture-reforms-roadmap-montek-panel (accessed on 2 September 2020).

31. IFPRI, Withering Punjab agriculture: can it regain its leadership? International Food Policy Research Institute, New Delhi, 2007; https://pdf.usaid.gov/pdf_docs/Pnadk223.pdf

32. Singh, G., Lack of diversification and declining growth profitability and surpluses from Punjab Agriculture. Res. Anal. Eval., 2012, $3(32), 42-44$.

33. Tiwari, R., Government on crop diversification in Punjab to save soil and water. The Economic Times, 2013; https://economictimes. indiatimes.com/news/economy/agriculture/government-for-crop-diversification-in-punjab-to-save-soil-water/articleshow/18784139.cms (accessed on 15 August 2020).

34. MoA, Crop diversification program in Haryana, Punjab \& Western Uttar Pradesh. Ministry of Agriculture, Government of India, 2014; http://agricoop.nic.in/sites/default/files/CDPGuidelines_0.pdf (accessed on 30 October 2020).

35. Brar, R. S., Crop diversification fails to take off, courtesy lack of Govt support. Hindustan Times, 21 August 2015; https://www. hindustantimes.com/punjab/crop-diversification-fails-to-take-off-courtesy-lack-of-govt-support/story-CELBH82m6nJUORXQKHUulL. html (accessed on 1 September 2020).

36. Pandey, S., Nudge didn't work, agriculture ministry now has a plan to force paddy farmers to diversify. ThePrint, 7 January 2020; https://theprint.in/india/governance/nudge-didnt-work-agricultureministry-now-has-a-plan-to-force-paddy-farmers-to-diversify/344974/ (accessed on 1 August 2020).

37. Saran, S., Kataria, P. and Kaur, A., An electricity energy usage and energy subsidy in Punjab agriculture. Indian J. Econ. Dev., 2013, 9(3), 404-413.

38. Pujara, M. and Shahid, A., Crop diversification: challenges of switching crops in Punjab. Indian J. Econ. Dev., 2016, 12(1a), 579. 
39. Singh, S., Rethinking diversification of agriculture in the Indian Punjab: an examination of strategy and mechanisms. In The Experience of Punjab, India (eds Singh, L. and Singh, N.), Springer, 2016, ch. 4.

40. Kaur, G., Crises of agriculture in Punjab: setbacks to diversification and role of state. Int. J. Adv. Sci. Res. Manage., 2018, 3(8), 197-200.

41. Raghavan, M., Politics of procurement and price support. Econ. Polit. Wkly, 2004, 39(5), 506-508.

42. GoI, Evaluation report on efficacy of minimum support prices (MSP) on farmers. NITI Aayog, Government of India, 2016.

43. Chaba, A. A., Punjab: pvt players pay 30 to $50 \%$ less than MSP as state fails to procure sunflower, maize. The Indian Express, 9 October 2020

44. Aditya, K. S., Subhash, S. P., Praveen, K. V., Nithyashree, M. L., Bhuvana, N. and Sharma, A. Awareness about minimum support price and it's impact on diversification decisions of framers in India. Asia Pac. Policy Stud., 2017, 4(3), 514-526.

45. Chand, R., Emerging trends and issues in public and private investments in Indian agriculture: a state wise analysis. Econ. Polit. Wkly, 2001, 56(2), 161-183.

46. Singh, P., Declining public investment in Indian agriculture after economic reforms: an interstate analysis. J. Manage. Public Policy, 2014, 6(1), 21-33.

47. Dhakal, A., Chinwan, D. and Ali, J., Effect of inadequate processing and cold storage unit on the horticultural crops of India. In 48 Annual Convention of the Indian Society of Agricultural Engineers and Symposium on Engineering Interventions in Conservation Agriculture, Maharana Pratap University of Agriculture and Technology, Udaipur, 2014; https://www.researchgate.net/ publication/282442592_Effect_of_Inadequate_Processing_and Cold_Storage_Unit_on_the_Horticultural_Crops_of_India (accessed on 6 November 2020).

48. GoP, Report of the Task Force for Agricultural Development in Punjab. Government of Punjab; https://niti.gov.in/writereaddata/ files/Punjab_Report_0.pdf (accessed on 1 October 2020).

49. Sally, M., Vegetable prices cool off as supply increases on harvesting in UP, Bihar and Punjab. The Economic Times, 2015; https://economictimes.indiatimes.com/industry/cons-products/food/ vegetable-prices-cool-off-as-supply-increases-on-harvesting-in-upbihar-punjab/articleshow/50004053.cms? from $=\mathrm{mdr}$ (accessed on 22 August 2020).

50. Sehgal, M., Potato glut: Punjab framers compelled to sell crops at Rs 1 per kg. India Today, 2017; https://www.indiatoday.in/india/ story/punjab-potato-farmers-pakistan-ban-973102-2017-04-23 (accessed on 30 August 2020).

51. Haque, T., Diversification of small farms in India: problems and prospects (Theme Paper). National Centre for Agricultural Economics and Policy Research, New Delhi, 2002; https://www. semanticscholar.org/paper/DIVERSIFICATION-OF-SMALL-FARMS-
IN-INDIA-\%3A-PROBLEMS-Haque/14b100bbc6fc31bc03101ae$1 \mathrm{~d} 3 \mathrm{~b} 2$ eeda04042a87 (accessed on 1 October 2020).

52. Jha, B., Tripathi, A. and Mohanty, B., Drivers of agricultural diversification in India, Haryana and the Greenbelt Farms of India. Working Paper Series No. E/303/2009, Institute of Economic Growth, University of Delhi Enclave North Campus, 2009; http://www.iegindia.org/upload/publication/Workpap/wp303.pdf

53. Shergill, H. S., Wheat and paddy cultivation and the question of optimal cropping pattern for Punjab. J. Punjab Stud., 2005, 12(2), 239-250.

54. Malik, V. and Kaur, R., Diversification of crops in Punjab: cost benefit analysis. Academicia, 2015, 5(3), 88-94.

55. Vatta, K. and Taneja, G., Water energy agriculture nexus in India: a case study of Punjab. Technical Report for USAID, Centres for International Projects Trust, New Delhi, 2018; https://www. researchgate.net/publication/338676511 (accessed on 17 October 2020).

56. Kumar, V., Study to evaluate success of diversification of agricultural crops in Haryana. Centre for Research in Rural and Industrial Development, 2017.

57. Basantray, A. K. and Nancharaiah, G., Relationship between crop diversification and farm income in Odisha - an empirical analysis. Agric. Econ. Res. Rev., 2017, 30 (Conference Issue), 45-58.

58. Bansal, H., Sharma, S., Kumar, R. and Singh, A., The factors influencing and various technological and socio-economic constraints for crop diversification in Haryana. Econ. Aff., 2020 65(3), 409-413.

59. GoI, Raising agricultural productivity and making farming remunerative for farmers. NITI Aayog, Government of India, 2015; https://niti.gov.in/sites/default/files/2019-07/RAP3.pdf (accessed on 12 October 2020).

60. Joshi, P. K., Rao, P. S. and Birthal, P. S., Diversification towards high value agriculture. Econ. Polit. Wkly, 2006, 41(26), $2747-$ 2753.

61. Singla, N., Innovations in agricultural marketing in India: a case study of supermarket in Punjab. In Financing Agriculture Value Chains in India (eds Mani, G., Joshi, P. K. and Ashok, M. V.), Springer, 2018.

62. Hicks, A., Review of the challenges and opportunities for rural infrastructure and agro-industries development in the Asia Pacific region. Food and Agriculture Organisation, Rome, Italy, 2007; http://www.fao.org/3/a-ag128e.pdf (accessed on 2 October 2020).

63. Gandhi, V. P., Growth and transformation of the agribusiness sector: drivers, models and challenges. Indian J. Agric. Econ., 2014, 69(1), 44-74.

Received 28 November 2020; accepted 9 December 2020

doi: $10.18520 / \mathrm{cs} / \mathrm{v} 120 / \mathrm{i} 8 / 1303-1307$ 